\title{
SYNERGIA W ARCHITEKTURZE. TOŻSAMOŚĆ NOWEGO MIASTA UZDROWISKOWEGO
}

DOI: 10.37660/integr.2020.6.2.8

\section{WPROWADZENIE}

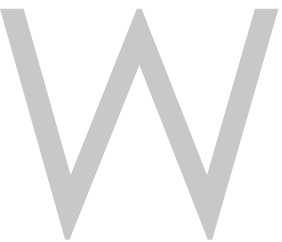

publikacji przedstawiono rozwijajaca się od 2015 roku współpracę pomiędzy Politechnikq Lubelska, reprezentowana przez SPA (Samodzielna Pracownię Architektoniczna z Wydziału Budownictwa i Architektury), a jednostkami samorzadu lokalnego w rejonie Polski wschodniej. Autora opracowania zainspirowała koncepcja organizacji warsztatów studenckich prof. dr. inż. Zbigniewa Bacia podczas odbywajacych się we Wrocławiu warsztatów „HABITATY 2014" oraz konferencji naukowej w których autor brał udział z asystentami arch. Piotrem Gleniem oraz arch. Aleksandra Jarockq-Mikrut.

W 2015 roku SPA rozpoczęło aktywne warsztatowe kształcenie studentów oraz organizację konferencję „Synergia w architekturze". Najpierw odbył się wyjazd studialny na „EXPO” w Mediolanie. Następnie w Zamościu zorganizowano studenckie warsztaty Przekształcenia terenów wokół Rotundy' (23-26 września 2015), w 2017 roku warsztaty Koncepcja Węzła Komunikacyjnego PKP-Bus-Rower, natomiast w 2018 roku Plac Melchiora Stefandesa-rewitalizacja. W 2019 roku SPA było organizatorem międzynarodowej konferencji Miasta wpisane na listę UNESCO. Poszanowanie Dziedzictwa pod patronatem UNESCO (Polski Komitet UNESCO), międzynarodowych warsztatów Rewitalizacja Pałacu Zamojskich na Centrum Kongresowo-Hotelowe z grupami studentów uczelni z Polski, Włoch, Litwy i Ukrainy. W kolejnych miastach uczestniczono w warsztatach edukacyjnych i w konferencji Pamięci Hetmana St. Żółkiewskiego - Żółkiewka 2016 r. oraz w warsztatach - Koncepcja Ośrodka rehabilitacyjnego z częścia hotelowa - Wożuczyn Cukrownia w 2017 r. W latach 2017-2019 w Zaklikowie prowadzono prace badawcze pod kierunkiem autora, dotyczace procesu integracji (miasto po 150 latach odzyskuje prawa miejskie), roli i znaczenia architektury w kształtowaniu miasta zwartego, studiów i analiz projekłowych dla nowego miasta uzdrowiskowego.

\section{ZAKLIKÓW}

Otrzymał prawa miejskie magdeburskie 9 kwietnia 1565 roku, z nadania króla Zygmunta Augusta. Miasto lokowano „na surowym korzeniu” - na gruntach wsi Zdziechowice. Otrzymało swoją nazwę od założyciela i właściciela Stanisława Zaklika z Czyżowa herbu Topór. W kolejnych latach miasto rozwijało się w woje-

dr hab. inż. arch. Jan Wrana prof. uczelni PL, https://orcid.org/0000-0002-4884-0418 Zakład Projekłowania Architektury, Katedra Architektury Współczesnej, Wydział Budownictwa i Architektury, Politechnika Lubelska, j.wrana@pollub.pl

1 J. Wrana, 2016. Synergia w nieidealnym „mieście idealnym” - próby integrowania Zamościa. Wydział Budownictwa i Architektury, Wydawnictwo Budownictwo i Architektura, Lublin. 


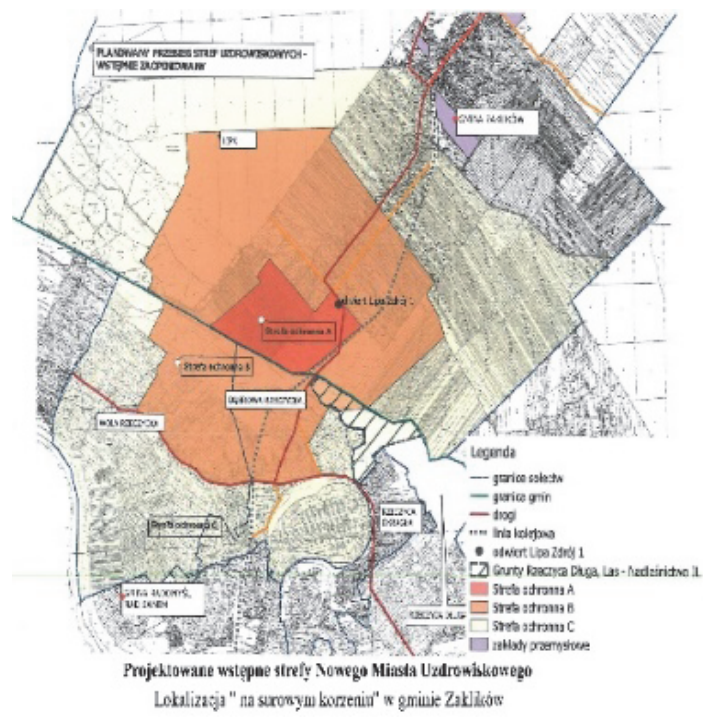

Uzdrowisko, pow. strefy „A", 91,04\% pow. biologiczna 1. Nałęczów134 ha, $75 \%$ pow. biologiczna

2. Duszniki-Zdrój 210 ha, $79 \%$ pow. biologiczna

3. Iwonicz-Zdrój 155 ha, 89\% pow. biologiczna

4. Supraśl 151 ha, $76 \%$ pow. biologiczna

5. Uniejów 156 ha, $97 \%$ pow. biologiczna

6. Wieniec-Zdrój 120 ha, $98 \%$ pow. biologiczna

Rys. 1. Projektowane wstępne strefy - kolor czerwony strefa "A" (115 ha), "lokalizacja na surowym korzeniu"

Fig. 1. The planned preliminary zones "A" (115 ha) new health resort town "foundation in crud a race" nicze klimatu z 2009 r. oraz b) świadectwo połwierdzające właściwości lecznicze surowca leczniczego, swoistej wody mineralnej z odwiertu „Lipa Zdrój-1". Należy przypomnieć że podczas poszukiwań złóż naturalnych w drugiej połowie XX W. natrafiono na bogate zasoby surowca leczniczego w miejscowości Lipa gmina Zaklików.

2 J. Wrana, A. Fitta-Spelina, 2017. Razem dla spójnego miasta. Zjawisko synergii na przykładzie współpracy Politechniki Lubelskiej i Urzędu Miasta Zaklikowa. PRZESTRZEŃ - URBANISTYKA - ARCHITEKTURA, nr 1, s. 217-232. Z teoretycznq wiedza akademicka wiąże się jej praktyczna, stosowana strona, czyli komercjalizacja: powstawanie i wdrażanie innowacji technologicznych oraz tworzenie nowych produktów i procesów.

3 M. Szmit, 2012. Rola uczelni wyższych w procesie rozwoju regionalnego: studium przypadku. [W:] Nierówności społeczne a wzrost gospodarczy - modernizacja dla spójności społeczno-ekonomicznej, M. Wożniak (red). Zeszyty Naukowe Uniwersytetu Rzeszowskiego, nr 18, s. 229. Obecnie rola uczelni najczęściej rozpatrywana jest na czterech płaszczyznach - jako jednostki ekonomicznej, producenta wiedzy, instyłucji kształcacej kapitał ludzki oraz instytucji będącej „aktorem regionalnym”. 
W dokumentacji z tamtego okresu przedstawiono wyniki badań wody z odwiertu w tej miejscowości: „Lecznicza woda mineralna, swoista 0,33\% siarczanowa, wapniowa, sodowa, siarczkowa" o znakomitym składzie i możliwościach leczniczych. Po kilkunastu konsultacjach Ministerstwo Zdrowia (Departament Organizacji i Ochrony Zdrowia) wstępnie zaakceptowało przebieg stref: „A" - kolor czerwony, "B" - kolor pomarańczowy i „C" - kolor żółty (rys. 1).

\section{OPRACOWANIE KONCEPCJI URBANISTYCZNEJ ZAGOSPODAROWANIA TE- RENU PLANOWANEJ STREFY„A"OCHRONY UZDROWISKOWEJ. ROZWIAZZANIA ALTERNATYWNE}

Tradycja miejsc uzdrowiskowych sięga w Polsce 1132 r., w którym pojawia się wzmianka o uzdrowisku Cieplice Zdrój. Obecnie w Polsce działa blisko 50 głównych uzdrowisk statutowych (oraz wiele miejscowości o walorach potencjalnie uzdrowiskowych). Planowane uzdrowisko Lipa Zdrój ma doskonałe proporcje powierzchni biologicznie czynnej.

Dla zleconego przez Urzad Miasta i Gminy Zaklików zakresu prac określonego w zawartej umowie autor publikacji kompletuje zespół projektowy do wykonania dwóch koncepcji ${ }^{4}$.

\section{Dostępność komunikacyjna}

Projektowane uzdrowisko Lipa zlokalizowane jest przy ważnych ciagach komunikacyjnych (kołowych, kolejowych):

- drodze wojewódzkiej DW 855, relacji: Oblęcin - Stalowa Wola,

- drodze krajowej DK 74, w kierunku Kielc oraz Kraśnika (pośrednio także Lublina),

- drodze krajowej DK 77, w kierunku Sandomierz oraz Przemyśla,

- linii kolejowej nr 68, relacji: Lublin - Stalowa Wola-Rozwadów - Przeworsk.

\section{Uwarunkowania prawne zwiq̨zane z funkcjonowaniem uzdrowiska}

Ustawa z dnia 28.07.2005 r. O lecznictwie uzdrowiskowym, uzdrowiskach i obszarach ochrony uzdrowiskowej oraz o gminach uzdrowiskowych definiuje po- jęcia określające lecznictwo uzdrowiskowe i jego formy oraz obszary spełniajace kryteria właściwe do ustanowienia takiej formy leczenia.

\section{Uwarunkowania rozwoju funkcji uzdrowiskowych}

Ważnym elementem krajobrazu gminy Zaklików są rozlegle lasy, bogate florystycznie, charakteryzujące się dostępnościa, co stanowi dodatkowy walor turystyczny.

Wybitne walory przyrodnicze i krajobrazowe stały się podstawa do objęcia niemal całej powierzchni gminy Zaklików rożnymi formami ochrony przyrodniczej i krajobrazowej. Część ustanowionych form ochrony obejmuje swoim zasięgiem także obszar przyszłego uzdrowiska Lipa.

\footnotetext{
4 Zespół do wykonania koncepcji 2: Opracowanie koncepcji funkcjonalnej Zakładu Balneologicznego (przychodnia z zabiegami leczniczymi w strefie uzdrowiskowej) - etap I (przedrealizacyjny uzdrowiska, rozwiazania alternatywne): główny projektant: dr hab. inż. arch. Jan Wrana, prof. uczelni PL, projektant: mgr inż. arch. Konrad Opasała. Dokumentacja wykonana przez zespół autorski została przekazana zamawiającemu w grudniu 2018 r.
} 


\section{Właściwości lecznicze klimatu}

urzad Miasta Zaklikowa gmina Zaklików pozyskał połwierdzenie leczniczych właściwości wody mineralnej z odwiertu wykonanego w miejscowości Lipa oraz właściwości leczniczych klimatu w tej miejscowości:

- Świadectwo potwierdzajace właściwości lecznicze klimatu miejscowości Lipa z 02.07.2013 r. - połwierdza właściwości lecznicze klimatu miejscowości Lipa w od- niesieniu do: chorób układu oddechowego, narządu ruchu i stanów pozaurazowych, chorób neurologicznych oraz zaburzeń układu termoregulacyjnego;

- Świadectwo potwierdzajace właściwości lecznicze naturalnego surowca leczniczego - wody mineralnej swoistej z odwiertu „Lipa Zdrój-1" na terenie miejscowości Lipa, gmina Zaklików - potwierdza, że woda mineralna siarczanowa, wapniowa, sodowa i siarczkowa z odwiertu „Lipa Zdrój-1" ma właściwości lecznicze w leczeniu chorób: skóry, tkanki łącznej, układu ruchu, układu nerwowego, układu krq̨żenia i współczesnych chorób cywilizacyjnych.

Z uwagi na swój skład woda ta może być wykorzystywana do kapieli leczniczych (balneoterapia) - teza przyjęta przez zespół ${ }^{5} \mathrm{~W}$ I ełapie przedinwestycyjnym "Laboratorium".

\section{KONCEPCJA ZAGOSPODAROWANIA STREFY„A” OCHRONY UZDROWISKOWEJ}

\section{Założenia funkcjonalno-przestrzenne dla strefy "A"}

Dla prawidłowego rozwoju i docelowego przekształcenia obszaru ochrony uzdrowiskowej w uzdrowisko niezbędne jest zrealizowanie szeregu inwestycji zlokalizowanych w strefie „A" (rys. 2).

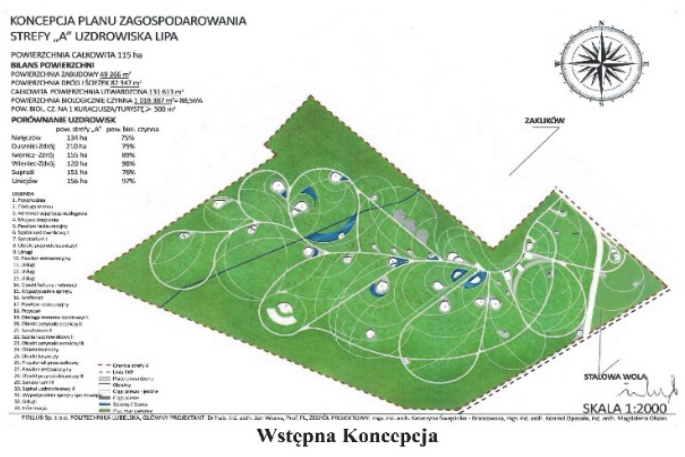

Rys. 2. Wstępna koncepcja planu zagospodarowania strefy „A"; realizacja planowana w III etapach

Fig. 2. The concept of the Zone "A" of the new heath resort in three stages
W koncepcji zaproponowano budowę następujacych obiektów uzdrowiskowych:

- I etap - realizacja zakładu balneologicznego (przychodnia zdrowia z wannami leczniczymi) wraz z towarzyszacym obiektem usługowym służącym obsłudze kuracjuszy; teren wskazany przez Ministerstwo Zdrowia dla strefy "A" uzdrowiska (rys. 1, kolor czerwony, o powierzchni 115 ha (o powierzchni biologicznie czynnej 91,04\% na 1 kuracjusza/turystę (ponad $500 \mathrm{~m}^{2}$ ) porównaliśmy z kilkoma aktywnymi uzdrowiskami;

\footnotetext{
5 Zespół projektowy koncepcji 1: Opracowanie Koncepcji Urbanistycznej Zagospodarowania Terenu, Planowanej strefy „A" Ochrony Uzdrowiskowej (Rozwiqzania Alternatywne oraz Koncepcji Miejscowego Planu Zagospodarowania Przestrzennego Strefy „A" Uzdrowiska "Lipa”: główny projektant: dr hab. inż. arch. Jan Wrana, prof. Uczelni PL, projektant: mgr inż. arch. Katarzyna Święcicka-Brzozowska, planista: mgr. inż. Ewa Banach, asystent: inż. arch. Magdalena Olszak, asystent: mgr inż. arch. Izabella Turkiewicz-Burzak, autor modelu biznesowego: mgr Jarosław Duda.
} 
- Il etap - realizacja zakładów lecznictwa uzdrowiskowego, takich jak: szpitale uzdrowiskowe, obiekty przyrodolecznicze i sanatoryjne oraz obiektów administracji uzdrowiska i obiektów usługowych (usług kultury, gastronomii), a także bazy noclegowej dla kuracjuszy;

- III etap - realizacja kolejnych obiektów leczniczych i usługowych oraz miejsc rekreacji i wypoczynku, takich jak: tereny sportowe, zbiornik wody z przystania wodna, ścieżki rowerowe, wypożyczalnie sprzętu sportowego, amfiteatr oraz inne obiekty kultury.

Pierwszym obiektem planowanym do realizacji we wstępnej fazie organizacji uzdrowiska jest zakład balneologiczny (rys. 3). Zamierzeniem władz gminy jest, aby na początku działalności sanatorium uruchomiony został zakład leczniczy, który będzie pełnił swoje usługi dla kuracjuszy i turystów. Zakład ma działać na zasadzie przychodni zdrowia z wannami leczniczymi. Przybywajacy kuracjusze w pierwszym etapie funkcjonowania sanatorium korzystać będa z bazy noclegowej oferowanej przez ośrodki wypoczynkowe funkcjonujace na terenie gminy oraz prowadzone

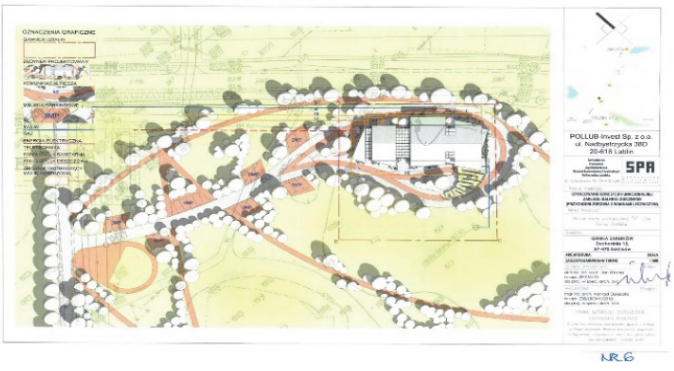

Rys. 3. Laboratorium - zakład balneologiczny nr 3 (przychodnia) - budynek 2-kondygnacyjny (test przedinwestycyjny)

Fig. 3. The launch of the Stage 2-buildings 3 (La-boratory - Balneological Institute), a part of the development plan (pre-investment test) przez miejscowa ludność pensjonaty i gospodarstwa agroturystyczne. Zamierzeniem władz gminy jest, aby uruchomienie funkcji sanatoryjnych na obszarze gminy słało się także przyczynkiem do rozwoju rożnych form usług turystycznych, prowadzonych przez jej mieszkańców.

\section{KONCEPCJA ZAKKADU BALNEOLOGICZNEGO. PRZYCHODNIA ZDROWIA}

Zakład balneologiczny zaprojektowany został na działce nr ew. 525/2 o powierzchni ok. 3000-3500 m², kłóra zostanie wydzielona z obecnej działki 525/1. Budynek umieszczono od strony drogi wojewódzkiej w odległości ok. 12 m od niej (fragment zagospodarowania terenu).

Obiekt nr $3^{6}$ zaprojektowany został jako obiekt uzdrowiskowy o funkcji zakładu balneologicznego (przychodni zdrowia z wannami leczniczymi). Podstawowym przeznaczeniem obiektu będa kąpiele wodne leczenie uzdrowiskowe, tj. balneoterapia. Budynek zakładu będzie stanowił zalążek uzdrowiska klimałyczno-zdrojowego. Został zaprojektowany z myśla o systemie lecznictwa otwartego, a zatem pacjenci skorzystaja z zakładu dochodząc lub dojeżdżajac do przychodni zdrojowej. Rozwiqzanie to spowoduje powstawanie infrastruktury pokoi noclegowych, pensjonatów, domów wczasowych i hoteli.

Dodatkowy obiekt nr 4 będzie pełnił funkcje obiektu referencyjnego, gdzie będzie można zaprosić zainteresowanych korzystaniem z uzdrowiska, a nawet zorganizować konferencję oraz plenery propagujace nową inwestycję i jej możliwości.

\footnotetext{
6 Koncepcja funkcjonalna Zakładu Balneologicznego (przychodnia zdrowia z wannami leczniczymi). Rozwiązanie alternatywne, arch. J. Wrana (główny projektant), arch. K. Opasała, 2018.
} 


\section{KONCEPCJA PLANU ZAGOSPODAROWANIA PRZESTRZENNEGO (ETAP II)}

Opisane powyżej obiekty nr 3 Laboratorium - zakład balneologiczny oraz 4 - usługowo-promocyjny sa przewidziane w I etapie, w okresie przygotowań i promocji nowego miasta uzdrowiskowego (rys. 4).

W drugim etapie (inwestycyjnym) zakładana jest budowa zespołu 15 obiektów lecznictwa uzdrowiskowego zlokalizowanych na obszarze pozostającym we władaniu gminy. Grupę obiektów leczniczych stanowić będa szpital uzdrowisko-

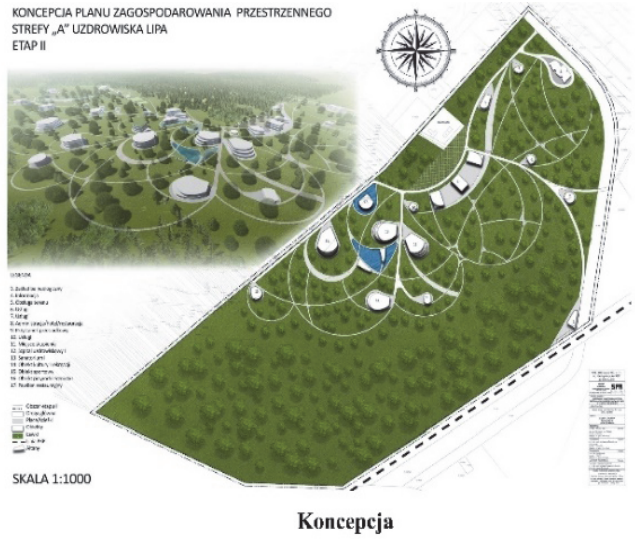

Rys. 4. Koncepcja planu zggospodarowania strefy "A" nowego miasta uzdrowiskowego etap II z wizualizacja

Fig. 4. The concept of Master Plan of the Stage 2 Zone "A" of Lipa-Zdrój health resort with visualization

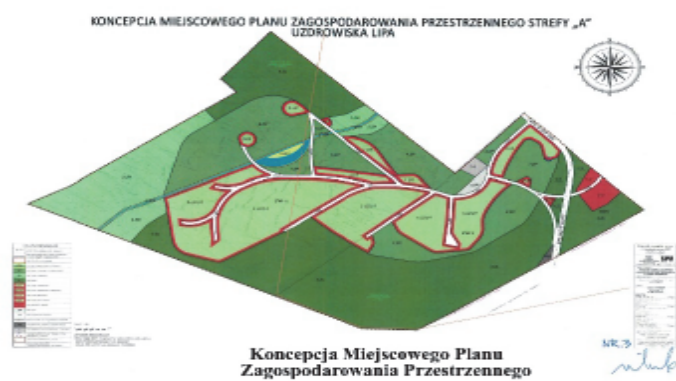

Rys. 5. Koncepcja miejscowego planu zagospodarowania przestrzennego

Fig. 5. Conception of Development Master Plan wy, sanatorium i obiekt przyrodoleczniczy. Obiekty towarzyszące to: pawilon restauracyjny, obiekt kultury, miejsce skupienia i 3 obiekty usługowe (rys. 5).

Obiekty pomocnicze, administracyjne i noclegowe proponowane do realizacji na tym etapie to kompleks trzech budynków dla administracji sanatorium i bazy noclegowej z parkingiem centralnym, obiekt dla obsługi terenu (służb technicznych i komunalnych), budynek informacji dla osób przybywających do sanatorium oraz budynek przystanku przesiadkowego przy granicy z droga powiatowa oraz stacja kolejowa.

Ostatni, trzeci etap realizacji przedsięwzięcia obejmuje zagospodarowanie terenów położonych najdalej od traktu komunikacyjnego, na północ od stref realizowanych w pierwszym i drugim etapie. Sa to tereny pozostajace obecnie we władaniu osób prywatnych i na pozyskanie ich do lokalizacji kolejnych obiektów sanatoryjnych konieczny będzie dłuższy okres. Stąd założeniem koncepcji jest etapowanie realizacji przedsięwzięcia, co pozwoli na uruchomienie funkcji sanatoryjnych i rozpoczęcie funkcjonowania sanatorium $w$ miarę szybko, bez konieczności oczekiwania na pełne zagospodarowanie strefy „A". W trzecim etapie zakłada się jest zagospodarowanie kolejnych 70 ha terenu i realizację kolejnych 23 obiektów.

Proponowane obiekty to: obiekty lecznicze (szpitale uzdrowiskowe, sanatorium, zakłady przyrodolecznicze), tereny sportowe i rekreacyjne z zespołem boisk, zbiornik wody z przystania, wypożyczalnie sprzętu sportowego, urządzenia rekreacyjne w zieleni parkowej oraz obiekty usługowe (restauracyjne i kultury). 


\section{ZASADY KSZTALTOWANIA PRZESTRZENI UZDROWISKA}

Koncepcję funkcjonalno-przestrzenna strefy ochrony uzdrowiskowej „A" nowego uzdrowiskowego "Lipa" sformułowano, przyjmując następujące zasady:

- realizacja uzdrowiska na terenie nie zainwestowanym zapewni wymagane ustawa o lecznictwie uzdrowiskowym, uzdrowiskach i obszarach ochrony uzdrowiskowej oraz o gminach uzdrowiskowych zachowanie odpowiedniej wielkości terenów zielonych, która wynosi dla strefy "A" nie mniej niż 65\% powierzchni strefy. Stad zasadna jest propozycja gminy ulokowania strefy ochronnej „A";

- obszar, na którym proponowana jest lokalizacja obiektów uzdrowiskowych, stanowi kluczowa lokalizację z akcentowana kompozycja zwartego ciagu uzdrowiskowego. Przyjęta zasada kształtująca tożsamość nowego powstajacego miasta jest „wpisany w wielohektarowy zalesiony teren układ urbanistyczny w formie »bukietu wiosennego kwiatów (obiektów i usług leczniczych), ułożonego na życiowej gałęzi/natury snującej się (z miejscami do aktywnej/ rekreacji) i symbolizujacej miejsce sprzyjajace odnowie witalneju". Teren ten otoczony będzie maksymalnie dużymi terenami zieleni;

- zabudowa uzdrowiskowa winna powstawać nie tylko wokół terenów leśnych, przekształconych i użyłkowanych jako park leśny, ale również wewnątrz leśnego parku uzdrowiskowego. Koncepcja zakłada stworzenie warunków do bezpośredniego kontakłu kuracjuszy z przyroda, w tym z wykorzystaniem unikatowych właściwości lokalnego klimatu.

\section{Leśny park uzdrowiskowy}

Walory przyrodnicze i krajobrazowe tego terenu predysponuja obszar otaczajacy przyszłe obiekły sanatoryjne do stworzenia dużej zielonej przestrzeni rekreacyjnej w formie leśnego parku uzdrowiskowego. Ukształtowanie tego terenu z przewaga powierzchni o łagodnym nachyleniu sprzyja budowaniu ciekawych kompozycji ścieżek spacerowych.

\section{Zasady kształtowania architektury}

Należy dążyć do tego, aby przyszłe uzdrowisko „Lipa” uzyskało wyjatkowy, niepowtarzalny, charakterystyczny dla siebie wyraz architektoniczny, uwzględniajacy jednolity detal, proporcje i materiał budowlany. Skala (wielkość), bryła i wyraz architektoniczny głównych obiektów uzdrowiska powinny nawiązywać do zdefiniowanych w ogólnym zakresie w ramach niniejszej koncepcji.

\section{PRACA DYPLOMOWA - NOWY OBIEKT SANATORYJNY W STREFIE „A" ZAPLECZA UZDROWISKA (stopień magisterski, autor: inż. arch. Magdalena Olszak)}

Dyplomantka, uzasadniając wybór tematu pracy, pisze na wstępie: Wybór tematu pracy dyplomowej jest związany przede wszystkim z chęcią zmierzenia się z dużym założeniem projekłowym, jakim jest sanatorium uzdrowiskowe. Na lokalizację wybrano miejscowość posiadająca duży potencjał, by stać się miejscowościa uzdrowiskowa poprzez wzglad na występowanie mineralnych wód posiadających właściwości lecznicze. Ponadto na jej terenie znajdują się znaczących rozmiarów niezagospodarowa-

\footnotetext{
Promotorem pracy dyplomowej był autor publikacji. Praca uzyskała ocenę 5 z wyróżnieniem, uczestniczy obecnie w wystawie prac dyplomowych 2018/2019 w budynku Wydziału Budownictwa i Architektury Politechniki Lubelskiej.
} 
ne tereny przeznaczone pod lokalizację uzdrowiska. Niniejszy projekt architektoniczny odpowiada na rzeczywiste potrzeby miejscowości, podejmując próbę wykorzystania naturalnych walorów opracowywanego obszaru, które sprzyjają rozwojowi gospodarki w zakresie działalności leczniczej oraz świadczenia usług opieki zdrowotnej.

Powierzchnia użytkowa $9622,2 \mathrm{~m}^{2}$,

Powierzchnia całkowita $13746,78 \mathrm{~m}^{2}$

Powierzchnia zabudowy $3297,00 \mathrm{~m}^{2} \quad$ Kubatura $52107 \mathrm{~m}^{3}$

Zasada kompozycji - „Obiekt wpisany w krajobraz obrzeża Parku Zdrojowego” (rys. 6)

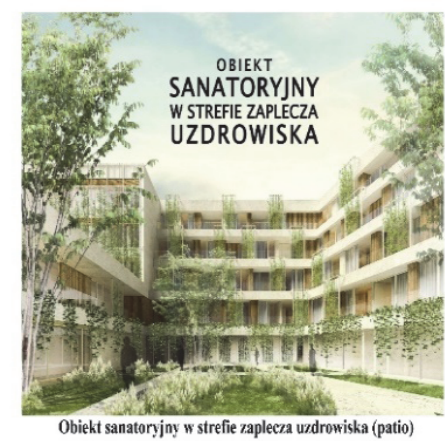

a

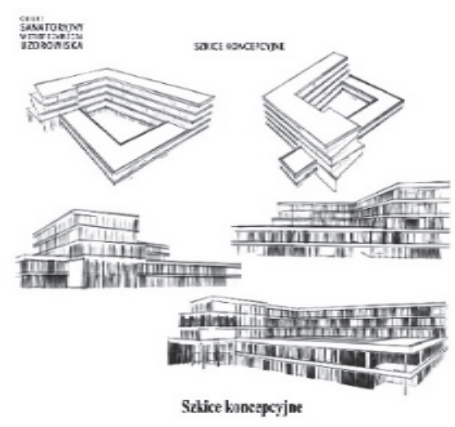

c

Rys. 6. Obiekt sanatoryjny w strefie zaplecza uzdrowiskowego, praca dyplomowa - stopień magisterski mgr inż. arch. Magdaleny Olszak, obrona grudzień 2019 r., promotor arch. Jan Wrana; $a$ - patio, b - rzut parteru z widokiem sanatorium, c - szkice, d-rzuty (I i ll piętro oraz widoki elewacji I-I II-II

Fig. 6. A health resort building in the back zone of the health resort (Master's degree thesis of Magdalena Olszak under the supervision of arch. Jan Wrana (author of the publication), a-patio, b-ground floor with view of building, c - sketches, $d$ - first and second floor and view of elevations

\section{Układ parkingów i komunikacji}

W celu poprawnego powiązania uzdrowiska z siecia dróg zewnętrznych oraz zagospodarowania przestrzeni strefy „A" projektuje się wyodrębnienie strefy wjazdowej, obejmujacej obszar recepcyjny uzdrowiska. Obszar położony w strefie „recepcyjnej” uzdrowiska należy trakłować jako teren o prestiżowej lokalizacji. Realizacja strefy wjazdowej winna nastąić w drugim etapie. Dla osób przyjeżdża- 
jacych do sanatorium komunikacja autobusowa lub kolejowa zlokalizowano przy południowej granicy strefy przystanek przesiadkowy w bezpośrednim sasiedztwie drogi powiatowej, w bliskiej odległości od trakłu kolejowego.

\section{Informacja o zakładanej infrastrukturze poszczególnych etapów projekłowych dla ich realizacji w strefie „A" uzdrowiska Lipa}

Ze względu na to, że na całym obszarze przeznaczonym pod uzdrowiskowe strefy „A", „B", „C" jest brak odpowiedniej infrastruktury technicznej, zakłada się W strefie "A" etap I i II - projektowanie lokalnej infrastruktury obsługi (mediów) oraz obiektów kubaturowych i dróg.

\section{PODSUMOWANIE}

Inicjując synergiczny dialog podczas spotkań z samorzadami i mieszkańcami miast Polski wschodniej, prowadząc równolegle warsztatowe kształcenie studentów oraz spinając wiedzę na konferencjach naukowych z cyklu „Synergia w architekturze" z praktycznym jej doskonaleniem w prowadzonych projektach, uzyskaliśmy unikalna szansę na wdrożenie procesu badawczego oraz interdyscyplinarnych analiz, kreując w czystym naturalnym krajobrazie: integrację sztuki i techniki w architekturze i urbanistyce. Wymagajacy krajobraz nowego uzdrowiska umożliwił kreację architektury i urbanistyki w symbiozie z otaczającym drzewostanem rozległych lasów oraz wypełnił „†ożsamość nowego miasta uzdrowiskowego" z założenia dla regeneracji zdrowia w leczeniu chorób: skóry, łkanki łącznej, układu ruchu, układu nerwowego, układu krążenia i współczesnych chorób cywilizacyjnych oraz aktywnej rekreacji ruchowej w projektowanym parku zdrojowym, z wykorzystaniem w obiektach nowych technologii ograniczajacych zużycie energii elektrycznej, cieplnej wraz z redukcja emisji $\mathrm{CO}_{2}^{8}$. Z uwagi na swój skład woda (z odwiertu) może być wykorzystywana do kapieli leczniczych (balneoterapia), i właśnie tę formę leczenia zaproponowano w koncepcji jako przewidziana do realizacji w pierwszym etapie zagospodarowania uzdrowiska.

\section{LITERATURA}

[1] Broniowski A., 1870. Balneografia krajowa: Swoszowice w roku 1869. Drukarnia "Czasu", Kraków.

[2] Hermaniuk J., 2010. Innowacyjny Klaster Zdrowie i Turystyka „Uzdrowiska-Perły Polski Wschodniej" - cele, działania, rezultaty. [W:] Współczesne trendy funkcjonowania uzdrowisk - klastering, J. Hermaniuk, J. Krupa (red. nauk.), Instytut Gospodarki Wyższej Szkoły Informatyki i Zarzadzania w Rzeszowie, Rzeszów.

[3] Konarzewski D., Kawulok M., 2009. Od wsi do uzdrowiska: dziedzictwo architektoniczne Wisły. [W:] Dziedzictwo architektoniczne Wisły, materiały do monografii Wisły, Urząd Miasta Wisła, nakładem Galerii „Na Gojach”.

[4] Łazarkowie M. i R., 2007. Uzdrowiska w Europie: teraźniejszość i rys historyczny. Wydawnictwo Akademickie Wyższej Szkoły Społeczno-Przyrodniczej im. Wincentego Pola, Lublin.

8 J. Wrana, W. Struzik, 2019. Badania dla uzyskania wysokiej jakości powietrza w architekturze. Przykład - „WICA” Wschodnie Innowacyjne Centrum Architektury, przestrzeń i FORMA, no 40, Czasopismo Naukowe, PAN o. Gdańsk. 
[5] Meuser P., Schimer C., 2006. New Hospital Buildings in Germany, vol. 1; General Hospitals and Health Centers, vol. 2, Specjalist Clinics and Medycal Departments, DOM.

[6] Rozporządzenie Ministra Zdrowia z dnia 9 lutego 2018 r. w sprawie określenia wymagań, jakim powinny odpowiadać zakłady i urzadzenia lecznictwa uzdrowiskowego - (Dz.U. z 2018 r., poz. 496).

[7] Szmit M., 2012. Rola uczelni wyższych w procesie rozwoju regionalnego: studium przypadku. [W:] Nierówności społeczne a wzrost gospodarczy - modernizacja dla spójności społeczno-ekonomicznej, M. Wożniak (red). Zeszyły Naukowe Uniwersytetu Rzeszowskiego, nr 18, s. 229.

[8] Ustawa z dnia 27 marca 2003 r. o planowaniu i zagospodarowaniu przestrzennym (Dz.U. z 2018 r., poz. 1945).

[9] Ustawa z dnia 28 lipca 2005 r. o lecznictwie uzdrowiskowym, uzdrowiskach i obszarach ochrony uzdrowiskowej oraz o gminach uzdrowiskowych (Dz.U. z 2017 r., poz. 1056).

[10] Węcławowicz-Bilska E., 1998. Zdrojowiska w strefie wpływów dużego miasta i aglomeracji. Zagadnienia programowo-przestrzenne. Politechnika Krakowska im. Tadeusza Kościuszki, monografia 226, Kraków.

[11] Wrana J., 2016. Synergia w nieidealnym „mieście idealnym” - próby integrowania Zamościa. Wydział Budownictwa i Architektury, Wydawnictwo Budownictwo i Architektura, Lublin.

[12] Wrana J., Fitta-Spelina A., 2017. Razem dla spójnego miasta. Zjawisko synergii na przykładzie współpracy Politechniki Lubelskiej i Urzędu Miasta Zaklikowa. PRZESTRZEŃ - URBANISTYKA - ARCHITEKTURA, nr 1, s. 217-232.

[13] Wrana J., Struzik W., 2019. Badania dla uzyskania wysokiej jakości powietrza W architekturze. Przykład - „WICA” Wschodnie Innowacyjne Centrum Architektury, przestrzeń i FORMA, no 40, Czasopismo Naukowe PAN o. Gdańsk.

[14] Wysocka E., Muchowski Z. (red. nauk.), 2010. Nałęczów: szanse i zagrożenia rozwoju miejscowości uzdrowiskowej. Materiały z ogólnopolskiej konferencji naukowej, Nałęczów 21 maja 2010 r., Pet† i-Wojciech Guz i Wspólnicy, Lublin.

\section{SYNERGIA W ARCHITEKTURZE. TOŻSAMOŚĆ NOWEGO MIASTA UZDROWISKOWEGO}

STRESZCZENIE. W publikacji przedstawiono realizację współpracy pomiędzy uczelnia - Politechnika Lubelska a samorzadem - Urzędem Miejskim w Zaklikowie w latach 2016-2018 przy prowadzonych pracach badawczych autora z zespołem, dotyczacych procesu integracji, roli i znaczenia architektury w kształtowaniu miasta zwartego oraz studiów i prac projektowych dla nowego miasta uzdrowiskowego w miejscowości Lipa gmina Zaklików. W dniu 16.03.2016 została podpisana umowa ramowa pomiędzy Politechnikq Lubelska a Urzędem Gminy Zaklików, a pierwszym działaniem było zorganizowanie warsztatów studenckich (w lipcu 2016 r.) dotyczacych dwóch koncepcji: przekształceń przestrzeni publicznej miasta oraz przebudowy i rozbudowy GOK Zaklików. Wynikiem rozwijającej się meryłorycznej współpracy było podpisanie w marcu 2017 roku porozumienia wyrażającego wolę współdziałania na rzecz przyszłego nowego miasta/uzdrowiska w miejscowości Lipa na terenie gminy Zaklików, zmierzajacego do uzyskania koncesji na eksploatację - odwiert Lipa Zdrój-1, po badaniach potwierdzających spełnienie wymagań dotyczących mineralnej wody leczniczej. Po uzyskaniu świadectw potwierdzających właściwości lecznicze wody, a także klimatu 
otrzymano zaopiniowany w Ministerstwie Zdrowia - Departamencie Organizacji i Ochrony Zdrowia plan wyznaczonych stref ochronnych „A", „B”, „C" nowego uzdrowiska. W roku 2018 podjęte zostały przez autora z zespołem pierwsze prace: Koncepcje urbanistyczne zagospodarowania terenu planowanej strefy „A" ochrony uzdrowiskowej - w dwóch wariantach oraz Koncepcje miejscowego planu zagospodarowania strefy „A" uzdrowisko z oszacowaniem wstępnego modelu biznesowego dla planowanego uzdrowiska. Uczestniczaca w pracach projektowych studentka Wydziału Budownictwa i Architektury Politechniki Lubelskiej (kierunku architektura i urbanistyka) inż. arch. Magdalena Olszak w 2018 roku podjęła pracę dyplomowa, kłóra obroniła z wyróżnieniem w grudniu 2019 roku. Promotorem pracy był autor publikacji.

Słowa kluczowe: inspiracja, rozpoznanie standardu uzdrowisk, kreacja nowego uzdrowiska

\section{SENERGY IN ARCHITEKTURE. THE IDENTITY OF NEW HEALTH RESORT}

SUMMARY. The article presents the collaboration between a Lublin University of Technology and a local government - Zaklików Town Hall in the years 2016-2018 during the research carried out by the author and his team on the integration process, the role and importance of the architecture in shaping a compact city, as well as studies and project works for a new health resort in Lipa, in the Zaklików Municipality. On 16.03.2016 a framework agreement was signed between Lublin University of Technology and the Municipality of Zaklików. The first stage of the project was the student workshops (organised in July 2016 on two topics: the transformation of the public town space and rebuilding and extension of the Cultural Centre of Zaklików. The result of growing cooperation was the conclusion of the future new town/health resort in Lipa in the Zaklików Municipality aimed at obtaining a con-cession for exploitation of the Lipa Zdrój-1 well, after the research which confirmed the requirements for mineral healing water. After obtaining certificates atteting the therapeutic poperlies of water and climate, the plan of designated protection zones "A", "B", "C" of the new health resort was approved by the ministry of Health - Deparment of Organization and Health Protection, in 2018, the author and his team started the first works - "Urban development concepts for the planned zone " $A$ " of health resort protection - in two variants" and "Conceps of the local development plan for zone " $A$ " of the health resort" with development of a preliminary business model for the planned health resort. In 2018 a student of architecture and urban study, participating in the project, Magdalena Olszak, engineer of architecture wrote her master thesis on the subject of the first spa building in the "new town", that she defended with distinction in December 2019.

Keywords: inspiration, recognising of the health resort standards, creation of a new health resort 